\title{
POVNET 논의 동향 및 우리의 대응방향
}

\author{
김형규 주 $\mathrm{OECD}$ 대표부 주재관
}

\section{목차}

I. 빈곤감소네트워크(POVNET)의 이해

II. POVNET 핵심문서의 이해

III. POVNET의 최근 활동동향

IV. 향후 논의이슈 전망

V. 우리나라의 대응방향

\section{I. 빈곤감소네트워크(POVNET)의 이해}

\section{POVNET의 연혁}

$\mathrm{OECD} / \mathrm{DAC}$ 산하의 6 개 주제별 네트워크 중 하나인 빈곤네트워크(POVNET)는 각 공여국 및 개발 국제기구들의 원조정책 수립 및 집행에 있어 빈곤친화적 고려를 강화시키기 위해 1998년에 설치 되었으며, 회원국들 간의 합의에 기반한 관련 가이드라인 수립 및 모니터링에 활동의 초점을 맞추 고 있다. 아울러, 개발원조를 통한 빈곤감소의 전략연구 및 성과사례의 이행과 확산 또한 중요한 맨데이트로 받아들여지고 있다. 이러한 POVNET의 일련의 활동목적을 보다 일관되고 제도적으로 달성하기 위해 현재까지 2개의 핵심문서 ["DAC guideline on poverty reduction(2001)", "Propoor growth policy guideline (2007)"]가 생산되었으며 세부 활동의 주제 및 범위는 동 문서에 기반하여 계획되고 추진되고 있다고 볼 수 있다. 아울러, 이러한 활동목적을 보다 구체적으로 실 현하기 위해 PONET 산하에는 2개 작업반 (Implementation, Empowerment)이 설치되어 운영되 고 있으며 주요 활동내용은 아래와 같다. 
〈표〉POVNET 산하 T/T 현황

\begin{tabular}{|l|l|}
\hline \multicolumn{1}{|c|}{ Implementation Task Team } & Empowerment Task Team \\
\hline - Pro-poor growth in DAC peer review & \\
- Joint learning events & • 빈곤친화적 성장전략 Policy guidance 발간 \\
- ODA for social protection & \\
- China-DAC study group & \\
\hline
\end{tabular}

\section{2. 네트워크의 구성}

POVNET에는 DAC 회원국들 중 참여를 원하는 국가들과 UNDP, IMF, $\mathrm{WB}$, 등 개발관련 국제기구 들, 기타 개발도상국의 경제성장에 직·간접적 영향을 미치는 $\mathrm{OECD}$ 산하기구(TUAC1), $\left.\mathrm{BIAC}^{2}\right)$ ) 등 이 참여하고 있다. 이외에도 논의주제에 따라 다양한 국제기구 및 시민사회 등이 참여하기도 한다.

\section{POVNET의 이념과 활동방향}

POVNET의 주요 관심사항과 활동의 전략적 방향을 이해하기 위해서는 아래의 글로벌 빈곤문제와 개발원조의 역할에 대한 POVNET의 관점을 우선 참고할 필요가 있다.

지난 세기 개발원조는 개발도상국 주민들의 삶의 질과 복지를 괄목할만하게 향상시켜온 것을 부인할 수는 없다. 평균수명은 20년 이상 증가되었고 유아사망률은 절반으로 줄어들었으며 초등학교 진학률은 $50 \%$ 이상 증가했다.

하지만 여전히 전 세계의 30 억 인구는 하루 2 달러 이하로 살아가고 있으며 이 중 10 억명은 하루 1달 러 이하의 위태로운 삶을 영위하고 있는 것이 여전한 현실이다. 특히 개발도상국의 빈곤퇴치를 위해 필수적 요소인 지속적 경제성장은 만족스럽지 못한 수준이며 이는 결국 전 인류의 과제인 MDGs의 실 패로 귀결될 수 있다.

아울러 급속한 세계화는 국가간·국가내에서의 경제적 불평등 심화 등 새로운 문제들을 대두시키고 있 으며, 글로벌 주류경제로부터 소외된 국가, 지역, 계층, 인종 등의 빈곤상황 악화는 폭력분쟁 등 지구 촌 안보불안으로 이어지고 있다. 나아가 빈곤은 범 지구적 차원에서 질병, 불법이민, 환경파괴, 범죄, 정치적불안, 무력분쟁, 테러 등 사회적 병리현상을 대두시키고 있으며, 특히 인구문제 ${ }^{3)}$ 의 심각성은 이 제 한 국가나 사회의 문제를 넘어서고 있다. 이러한 맥락에서 빈곤퇴치 이슈는 이제 도덕적-인도주의 의 관점을 넘어 지구안보와 공동번영에 절대적인 요소로 자리잡고 있으며 우리 모두를 위한 최우선순 위의 공공재이다.

1) Trade Union Advisory Committee

2) Business and Industry Advisory Committee

3) 향후 20 년간 20 억의 인구가 증대될것으로 전망되되고 $97 \%$ 가 개발도상국에서 거주한다.(DAC guideline on poverty 
하지만 이러한 위기속에서도 기회를 발견할 수 있는 것은 세계화로 대변되는 새로운 글로벌 역학으로 인해 촉진되는 국가들 간의 경제통합은 새로운 소득과 고용의 동력이 되고 있으며 이는 생산과 교역을 촉진시키고 있다. 이러한 현상은 의사소통, 상호학습의 유래 없는 형태가 되어 개발도상국 주민들에게 도 기회를 확대하고 있으나 실제로 빈곤층에게 직접적으로 이 기회가 전달되도록 전략적-제도적 노력 을 기울여야 하며 아울러 이 기회를 빈곤층이 활용할 수 있도록 역량을 강화시키는 것이 무엇보다 중 요하다. 이러한 상황과 관점에 기반하여 개발커뮤니티는 조화되고 초점을 가지고 효과적으로 글로벌 빈곤문제를 공략해나갈 필요가 있다.

〈DAC guideline on poverty reduction에서 발췌 및 요약정리〉

상기와 같은 관점 및 목표의식에 기반하여 POVNET은 개발도상국의 실질적 빈곤감소에 초점을 맞춘 개발원조의 방식과 규범을 제시하기 위해 가이드라인 수립, 연구조사, 상호학습 및 토론, 교 육프로그램 운영 등을 추진하고 있다. 특히, 근래 POVNET 논의의 중심을 차지하고 있는 주제는 “빈곤감소를 위한 경제성장의 역할과 중요성”에 관한 것이다. 하지만 경제성장률 등 외형적 수치 보다는 성장의 내용과 질에 대한 관심이 높은데, 즉 거시경제 성장이 필연적으로 빈곤완화 혹은 빈곤층 감소를 수반하지 않거나 상대적 소외를 심화시킬 수 있다는 전제에서 경제성장의 혜택이 실제 빈곤계층에게 직·간접적으로 미칠 수 있는 성장의 유형과 방법에 대해 고민하고 모범사례를 확산시키는 데 초점을 맞추는 것이다. 따라서 경제성장의 내용측면에서 빈곤층의 고용확대를 수반 하는지의 여부, 빈곤층이 집중되어 있는 농촌지역의 사회기반 및 생산기반 개선 가능성, 농업생산 성 제고, 사회보장프로그램 개선 여부 등을 중점적으로 분석한다.

이러한 맥락에서 POVNET은 개발원조 또한 개발도상국의 빈곤층/지역에 직접적 혜택을 줄 수 있 고 나아가 질적 측면의 경제성장을 지원해야 한다는 관점에서 각 공여국들의 원조정책 및 집행 차 원의 빈곤친화적 모범사례와 정보를 공유하고 이를 원조규범화시키는 데 활동의 역점을 두고 있 다. 보다 구체적으로는 개발도상국의 실질적인 빈곤퇴치를 위해 필수적인 인프라구축, 농업생산성 강화, 무역과 투자관련 능력배양, 정보 커뮤니케이션 기술 발전, 중소기업 육성 등에 대한 개발원 조 확대 및 바람직한 접근방법을 연구하고 이에 근간환 이행의 확산을 위해 노력하고 있으며, 최 근에는 대안적 이행수단으로써 민관 파트너십(PPP)의 역할 등에 대한 적극적인 연구와 논의도 병 행하고 있다. 나아가 필요한 경우에는 특정 수원국을 대상으로 빈곤친화적 관점의 국가빈곤퇴치 전략수립을 지원하기도 한다.

reduction 전문) 


\section{POVNET 핵심문서의 이해}

POVNET 고유의 관점과 전략을 이해하기 위해서는 POVNET 활동의 기반이 되는 양대 문서인 아 래의 2 개 가이드라인에 대한 분석이 필요하다.

\section{DAC guideline on poverty reduction (2001)}

동 가이드라인은 $\mathrm{MDGs}$ 선언 직후 발간되었으며, 2015년까지 전 세계 극빈층을 절반으로 줄인다 는 인류공동의 목표와 기여약속을 담은 $\mathrm{MDGs}$ 의 달성을 지원하는 핵심적 수단이 되는 개발원조의 대안적 집행방식과 규범을 제시하는데 초점을 맞추고 있다. 동 가이드라인 내용은 기존 $\mathrm{OECD} /$ DAC의 핵심문서인 "Shaping the 21st Century"4) 에 기초하고 있으나 개발도상국의 빈곤퇴치를 위한 개발원조의 구체적이고 대안적인 집행방식 및 접근을 핵심내용으로 하고 있다.

주요 내용을 살펴보면, 우선 공여국 주도의 개발원조에 비해 수원국 주도의 원조 프로젝트들이 현 지 주민들의 복지와 삶에 보다 지속적인 영향을 끼칠 수 있다는 전제하에 개발원조의 지원형태와 방법에 있어 우선적으로 수원국 자체의 개발전략 및 빈곤퇴치계획을 반영하여 외부원조와 수원국 자체의 노력 및 개발재원이 분산되지 않아야 하며, 분야별 지원의 경우에도 실제 빈곤과 불평등이 해소될 수 있는 방향에 우선순위를 두고 기획·집행되어야 함을 권고하고 있다. 아울러, 다양한 형 태의 원조방식(프로그램, 프로젝트, 분야별지원 등)이 상호조화되어 시너지와 보완성을 도출할 수 있어야 하며 특히 기술협력의 중심목적은 수원국의 빈곤퇴치 역량강화가 되어야 한다는 내용을 포 함하고 있다. 아울러 Policy Coherence for Development(PCD)에 대한 중요성도 이미 강조하고 있는데, 개발도상국의 빈곤퇴치 노력과 이에 대한 개발원조의 기여가 실질적인 성과를 얻기 위해 서는 공여국의 개발정책 이외의 타 대외정책들이 개발친화성을 가져야 하며 이에 필요한 정치적 조치를 구현해 내기 위해서는 각 공여국들의 원조기관이 핵심적 역할을 수행해야 한다고 권고하고 있다.

\section{Pro-poor growth guideline (2007)}

최근 POVNET 활동의 가장 근간이 되고 있는 문서로써 이전 DAC Guidelines on Poverty Reduction 에 비해 보다 거시적 관점에서 빈곤문제 해결전략을 제시하고 있으며, 이러한 전략에 기초한 수원

4) Shaping the 21st Century : The Contribution of Development Co-operation, 1996년 OECD/DAC에 의해 수립된 개발원조의 핵심문서로써 파리선언 및 $\mathrm{AAA}$ 의 이론적 기반이 됨 
국들의 개발정책 수립방향과 아울러 빈곤친화적 성장을 위한 개발원조의 기여방안도 함께 제시하 고 있다.

우선, 빈곤문제가 매우 복합적이며 경제, 정치, 사회문화, 치안 등 다양한 요소들과 연계되고 상 호작용하고 있음을 전제하고 보다 폭넓은 관점에서 경제성장이 다른 정책분야들과 어떻게 우호적 으로 상호작용하며 통합적으로 빈곤감소 성과를 나타낼 수 있는 지에 대한 이해를 제고시키는데 내용의 중점을 두고 있다. 빠르고 지속적인 빈곤감소를 위해서는 성장이 빈곤친화적으로 진행되어 주민들이 성장과정에 참여하고 혜택을 받을 수 있어야 하며 따라서 국가의 성장정책은 단순히 경 제성장률 뿐 아니라 성장의 형태와 질에 대한 고려를 강화하여 지속적인 빈곤퇴치 효과를 가져올 수 있어야 한다는 것이다. 특히, 성장정책들이 젠더이슈, 환경 등을 포함한 빈곤문제와 밀접한 관 련이 있는 부문들과 상호작용하고 공조를 유지할 때 성장정책이 다른 분야의 발전을 촉진하고 긍 정적 영향을 미칠 수 있으므로 빈곤문제를 독립적인 분야로 분리시키는 이분법적 접근은 지양되어 야 한다고 지적한다. 특히, 빈곤층의 역량강화는 빈곤친화적 성장에 필요한 정책과 투자를 활성화 시키는데 무엇보다 중요한 요소이므로 성장전략 추진과정에서 특별한 노력을 기울일 필요가 있으 며, 빈곤층에 대한 단순지원 보다 이들의 경제활동을 확대하는데 필요한 재원을 투자하는 것은 매 우 중요하다.

개발원조의 측면에서도 이러한 고려는 매우 중요하며, 특히 공여국들은 수원국들의 빈곤친화적 성 장전략을 지원하는데 관심을 기울여야 한다. 개발원조사업의 집행단계에서도 빈곤의 다양한 원인, 국가별 상황, 빈곤층에 가장 영향을 미치는 정책 등에 대한 이해를 강화해야 하며 개발원조가 지 원하는 경제성장 전략이 수원국의 빈곤층에 미치는 영향에 대한 정확한 이해를 선행시켜야 한다. 동 가이드라인에서 나타나는 빈곤친화적 성장의 핵심관점은 아래와 같다.

(1) 경제성장은 빈곤퇴치의 기본적·핵심적 요소지만 경제성장이 지속되기 위해서는 성장이 분야와 지역 전반에 걸쳐 진행되어야 하며 다양한 계층, 특히 빈곤층을 포괄하여 진행되어야 함.

(2) 경제성장이 빈곤감소에 실질적인 기여를 해야하며 이를 위해서는 성장이 빈곤지역 및 계층에서 진행되는지가 중요하며, 국가의 정책은 이를 실현하기 위한 여건을 조성하고 경제성장과정에 토지와 노동자본시장 접근성을 확대하고 기초사회서비스, 사회보장, 인프라에 대한 투자확대를 통해 빈곤층의 참여가능성을 제고시켜야 함.

(3) 빈곤층의 불평등한 기회와 자산은 빈곤층이 성장에 기여 또는 참여기회를 제한시키고 소득불균 형은 사회적 통합을 저해하여 불안정을 유발켜 결국 경제성장 자체를 저해할 수 있음.

(4) 빈곤층의 취약성은 성장과정에서 나타나는 위기가 수반되는 기회를 회피하게 하므로 위기에 대 응할 수 있는 최소한의 사회보장을 확대해야 함. 
(5) 성장과정에서 빈곤층의 시장접근성 제고는 매우 중요하며, 특히 시장실패와 같은 상황에서 빈 곤층에게 더 유리하도록 관련 프로그램들이 디자인되어야 함.

아울러 빈곤친화적 성장전략과 관련한 공여국들의 개발원조 지원방식은;

(1) 공여국들은 수원국이 자체적으로 추진하고 있는 빈곤친화적 성장정책을 지원해야 하며, 개발원 조사업의 집행시 빈곤층의 이익 및 역량강화를 염두에 두어야 함.

(2) 공여국의 지원은 각 수원국의 거버넌스 국가별 상황(분쟁취약국 등)을 적절히 고려하여 유연하 고 대응적이어야 함.

(3) 공역국들은 민간부문개발, 농업, 인프라, 위기와 취약, 사회보장 등 빈곤친화적 성장과 관련이 높은 분야에 대한 지원을 강화해야 함.

(4) 공여국들은 수원국의 빈곤친화적 성장을 지원할 수 있는 자체적 역량을 강화해야 함.

\section{POVNET의 최근 활동동향}

최근 진행되고 있는 PONVET의 활동주제는 크게 이행(Implementation)과 역량강화(Empowerment) 로 구분하여 파악할 수 있다. Implementation 범주 내에서는 Pro-poor growth in DAC peer review, Joint learning events, ODA for social protection, China-DAC study group 등에 대한 작업들 이 진행 중이며, Empowerment 활동으로써는 Policy guidance 수립을 추진하고 있다.

\section{Implementation}

\section{1) Pro-poor growth in DAC peer review5)}

POVNET에서는 빈곤친화적 성장 이슈를 보다 체계적이고 효과적으로 각 공여국들의 개발정책에 반영하기 위해 DAC 동료검토 항목 및 절차에 포함시키는 노력을 기울여 왔다. 현재 이러한 방향에 대한 공감대가 확산되어 있는 상태이며 첫 단계로써 2006년 동료검토 지침서에 policy guidance on promoting pro-poor growth와 관련한 사항을 심사항목에 반영시킨 바 있다. 아울러 20112012 적용을 목표로 개정작업이 진행되고 있는 동료검토 지침서(Peer Review Contents Guide)에

5) OECD/DAC은 매년 4-5개의 회원국들을 대상으로 동료검토를 실시하여 각 국의 원조정책 및 집행현황, DAC에서 제 시하는 각종 원조의 규범 이행여부 등을 조사하고 있으며 동 검토절차에 적용되는 지침으로는 동료검토 contents guide가 별도로 있음(2년마다 개정). 
빈곤친화적 성장 가이드라인의 핵심내용들을 반영시키고자 노력을 기울였으며 2010.4.30 진행된 동료검토 방법론 회의에서는 이러한 POVNET의 제안에 대해 참석자들이 우호적인 반응들이 표시 함에 따라 2010.8.24 DAC 회의에서 빈곤친화적 성장 이슈 등 새로운 내용을 포함한 DAC 동료검 토지침의 개정(안)이 승인되었다. 향후 동 new contents guide는 2011년 동료심사부터 적용될 예 정이다.

\section{2) joint learaing events}

POVNET은 2006년부터 네트워크의 핵심사업 중 하나로 Train4Dev 네트워크6)와 전략적 제휴관 계를 맺고 빈곤친화적 성장과 관련한 이슈들에 대한 학습 이벤트를 수원국 현장에서 진행해 오고 있다. 현재 8 개의 주제별 교육과정을 개설하여 현장의 공여국 개발인력들에게 빈곤친화적 성장 관 련 지식 및 기술을 제공하고 있다. POVNET에서는 이러한 교육을 받은 개발인력들이 수원국과의 정책대화 등에서 빈곤친화적 성장 전략 관점을 효과적으로 반영시킬 것으로 기대하고 있다. 8개 과정이 다루고 있는 주제는 농업, 민간부문개발, 인프라, 무역 등에 걸쳐 있는데 상세한 과정명은 아래와 같다.

(1) Using political economy analysis to implement effective pro-poor policies.

(2) Policies for marginalised small farmers with few assets.

(3) Farm input subsidies.

(4) Increasing revenue collection without damaging the livelihoods of poor people.

(5) Liberalisation of export-oriented commodity markets and poor people.

(6) Labour-based approaches in the delivery and maintenance of publicly funded infrastructure.

(7) How should governments and donors encourage the private entrepreneurial activity of poor people and private sector development that is critical for pro-poor growth?

(8) Public work programmes and social protection.

아울러 POVNET은, 2010년 사회보장(social protection)에 관한 교육과정을 추가로 개설하기로 합의함에 따라 Train4Dev Network에서도 동 주제의 교육과정 운영을 위한 별도 작업반을 구성 중에 있으며 이러한 새로운 시도에 대해 오스트리아, 유로에이드, 독일, ILO, 아일랜드, 스웨덴, 스위스, 영국 및 WBI 등이 재정지원을 약속한 바 있다.

6) Training4Dev는 원조현장의 개발역량 강화를 위해 관련 교육훈련 프로그램을 필드인력 및 수원국 개발인력들에게 제 공하는 것을 목적으로 2003년 유럽 공여국들을 중심으로 설립되었으며 빈곤퇴치와 관련된 다양한 주제 및 접근 등에 대한 교육이벤트를 개최하고 있음 


\section{3) ODA for social protection}

근래에 들어 다수의 회원국들로부터 POVNET의 핵심이슈로 사회보장(social protection)7)을 포함 하자는 제안이 지속적으로 제기됨에 따라 사무국에서는 최근 각 공여국들의 사회보장 관련 개발사 업 추진현황 및 투입재원 등에 대한 조사를 실시한 바 있으며 동 조사의 결과를 기초로 동 이슈에 대한 향후 논의방향을 결정해 나갈 예정이다.

\section{4) China-DAC study group}

China-DAC 스터디 그룹은 중국의 경제성장 전략 및 아프리카 원조성과를 공유하는 국제적 플 랫폼 구축 차원에서 2009년 1월 중국 국제빈곤퇴치센터(IPRCC)와 DAC에 의해 출범되었다. 중국 은 이미 아프리카 지원에 있어 주요 공여국8)으로 대두되었을 뿐 아니라 기존의 인프라 위주의 지 원에서 $\mathrm{DAC}$ 공여국들이 중점을 두고 있는 거버넌스, 인적자원개발 등 이른바 'soft' 분야로 급속 히 지원영역을 확대해 가고 있는 현실에서 전략적이고 효과적인 아프리카 지원을 위해서는 중국과 의 파트너십 구축이 필수적이라는 인식이 동 스터디 그룹의 출범배경이 되었다. 이러한 목적하에 China-DAC 스터디 그룹은 아래의 3 가지 이슈들에 논의의 초점을 맞추고 있다.

i) agriculture, food security and rural development;

ii) infrastructure; and

iii) the enabling environment for enterprise development.

상기 주제들에 대해 DAC 회원국들이 특별히 관심을 가지는 측면은 중국이 지난 30년간 성장과정 에서 얻은 빈곤퇴치 및 외부원조 활용 경험과 아울러, 동 경험들을 적용한 대 아프리카 원조전략 의 시사점에 관한 것이다. POVNET에서는 이러한 시사점을 기존의 DAC 개발전략과 통합하여 보 다 효과적인 대 아프리카 지원전략 및 접근법을 모색하고 있다. 이러한 목적하에 2009년 이후 China-DAC Study Group은 특히 POVNET 이슈와 밀접한 관련성을 갖는 농업, 식량안보, 농촌 개발 및 인프라 등에 대한 주제로 이벤트를 진행시켜왔다.

DAC-china group의 출범 이전인 2008.2월 OECD에서 개최된 "DAC/POVNET 빈곤감소와 빈곤 친화적 성장 workshop"에 참여한 중국은 자국 및 아프리카에서의 농촌빈곤퇴치 모범사례들을 발 표한 바 있으며, 2010년 4월 농업, 농촌개발 및 식량안보를 주제로 말리에서 개최된 워크숍에는

7) 사회보장 이슈는 OECD/DAC의 2011-2012 활동 및 예산계획(PWB)의 Economic growth and policy 항목내에 녹색성 장 및 식량안보와 함께 3 대 핵심분야로 포함되어 있음.

8) 2007-2008 중국의 아프리카 지역 인프라 관련 원조규모는 50 억불에 달하고 있음(OECD/2010) 
중국, 아프리카 및 $\mathrm{DAC}$ 공여국들에서 100 여명 이상이 참석하여 한 바 있다. 이러한 일련의 지식 워크숍들은 전통적-신흥 공여국간, 지역간 상호이해 및 학습을 제고시키며 아프리카의 개발문제 와 빈곤퇴치를 위한 보다 결집된 노력을 가능케 할 것으로 기대하고 있다. DAC-China Study Group에서는 이러한 논의를 통해 다른 개발도상국에도 적용가능한 중국의 개발경험들이 도출되었 으며 특히 높은 수준의 주인의식, 장·단기 개발목표 설정, 인적자원개발 및 역량강화가 경제성장 과 빈곤퇴치의 핵심적 요소임을 증명했다고 평가하고 있다. 구체적인 사례로써, 중국의 경우 농촌 지역의 인프라 개선의 중요성을 강조하고 지속적인 투자를 실시함에 따라 실제 소농들의 경제성장 기반이 마련되었다고 조사되었으며, 해외원조 접근방식과 관련하여 $\mathrm{DAC}$ 회원국들이 파트너십에 기초한 파리선언의 원칙에 초점을 맞출때 중국은 보다 사업적인 접근을 강조하여 양허적 비양허적 수단을 동시에 사용하여 지원의 지속성을 향상시켰다는 것이다.

이러한 성과를 기반으로 향후 동 그룹은 2011년 1월 에티오피아 아디스아바바에서 4차 행사를 가 질 예정이고, 2011년 4월에는 중국에서 정책심포지움을 개최할 예정이다. 특히, 동 심포지움은 향 후 DAC-China Study Group의 향후 발전방향을 논의하는 장이 될 것으로 예상하고 있다. DAC 차원에서도 동 그룹에 대한 관심과 지원을 확대하고 있으며 DAC의 2011-2012년 예산계획에도 관 련 사업계획들이 공식적으로 반영되어 있는 상태이다.

\section{Empowerment}

동 work stream의 목적은 공여국들의 빈곤친화적 성장과 관련된 역량을 강화하는데 있으며 현재 진행되고 있는 핵심작업은 “역량강화 가이던스” 작성이다. 동 가이던스는 각 공여국들로부터 수집 된 빈곤친화적 성장 전략과 관련한 분쟁취약국에서의 성공사례, 여성 역량 강화 모범사례, 모니터 링 결과 등에 기반하여 수립되고 있으며 타겟 그룹은 공여기관 본부 및 현장인력들로 규정하고 있 다. 최근 동 가이던스에 추가로 반영이 필요한 사항으로 토지권, 사회보장, 시민권과 관련된 주민들 의 역량강화들이다. 최근 보고에 따르면 Empowerment $\mathrm{T} / \mathrm{T}$ 은 정책결정자를 대상으로 한 Policy Guidance와 더불어 원조활동가를 대상으로 한 Good Practice Note $e^{9}$ 를 병행해서 작성 중에 있으 며 Policy Guidance는 초안을 완성한 상태이고, Good Practice Note는 $50 \%$ 의 진척율을 보이고 있다.

9) Donor Support for Empowerment Processes Underpinning Pro-poor Growth 


\section{POVNET의 향후 논의이슈 전망}

OECD/DAC의 2011-2012 사업예산계획(PWB)에서는 동 기간 핵심 논의의제로 원조효과성, aid architecture, aif for trade, 인도적 지원,녹 색성장과 빈곤, 글로벌 식량안보, 사회보장 등을 제 시하고 있으며, POVNET은 동 이슈 중 POVNET과 밀접한 연관성을 가지는 주제들인 글로벌 식 량안보, 글로벌 사회보장 기반 확대, 녹생성장과 빈곤감소 이슈들에 대해 활동의 초점을 맞출 것 으로 전망된다. 아울러 금년도 개최된 서울G20의 개발의제 및 $\mathrm{HLF}-4$ 기여방안 등도 주요 의제 로 부상될 것으로 예상된다.

\section{G20 Seoul Summit 개발이슈와 POVNET}

2010 서울 $\mathrm{G} 20$ 개발의제와 관련하여 그간 $\mathrm{OECD}$ 는 다년간 행동계획(Action plan)10) 수립을 중심 으로 참여와 기여를 한 바 있으며, 향후 동 기여의 연속선상에서 POVNET도 빈곤퇴치와 관련된 행동계획 대한 이행촉진과 모니터링 에 참여하고자 하는 의지를 보이고 있다. 특히, G20 개발의제 의 성장지향적 관점에 POVNET의 빈곤친화적 성장전략을 적극적으로 반영함과 아울러, 식량안보, 취약계층 보호를 위한 사회보장 이슈, 금융소외계층 포용 등의 행동계획 항목에 대해 POVNET 차 원의 구체적 기여방안을 모색하고 있다.

G20 서울 정상회의 다년간 개발 행동계획 중 POVNET의 관점을 적용할 수 있는 항목과 접근관점 은 다음과 같이 요약될 수 있다.

- 인프라 (Infrastructure) : 포괄적 인프라 행동계획 구축

- 농촌 및 빈곤지역의 인프라 개선은 개발도상국 빈곤퇴치의 중요한 원동력이 되므로 우선적 인 노력을 기울여야 함.

- 식량안보(Food Security) : 가격 변동성 위험 완화 및 취약계층 보호

- 개발도상국에서 농산물 시장의 왜곡과 가격변동성은 특히 취약계층에게 위기를 증가시킴으 로 친빈곤층 위험관리정책을 수립하고 소농의 구매 및 시장접근 확대 등의 조치를 취해야 함.

- 복원력 있는 경제성장(Growth with Resilience) : 개도국 사회보호체제 강화

- 경기위기 및 침체는 특히 취약계층에게 영향이 큼으로 빈곤층 등을 위한 최소한의 사회보장 시스템 구축을 진전시켜야 함.

- 빈곤층의 금융 및 자본 접근성을 향상시켜 빈곤층의 빈곤탈출 및 삶의 질 향상 기회 확대

10) 2010.11 월 개최된 서울 G20 정상회의에서는 6 개의 개발의제 원칙이 합의되고 9 개 개발 주요분야에서 '다년간 개발 액션플랜'이 도출됨. 


\section{Road to Busan}

원조효과작업반(WP-EFF)에서는 2011.11월 부산에서 개최될 예정인 원조효과고위급포럼(HLF-4) 에서 $\mathrm{PD} / \mathrm{AAA}$ 이행에 대한 최종평가와 아울러 2015년 이후를 위한 aid quality framework 발굴 및 최근 논의가 활발히 진행되고 있는 aid quality in the broader context of development effectiveness 등이 핵심의제가 될 것으로 전망하고 있다. 이러한 예측에 대응하여 POVNET에서 도 $\mathrm{HLF}-4$ 준비과정에서 pro-poor growth 관점에서의 PD/AAA 평가분석과 post-HLF4 이슈 중 하나로 social protection을 포함시키는 방안을 검토하고 있다.

\section{3. 글로벌 사회보장 체계}

사회보장(social protection) 이슈는 2009년에 이미 POVNET의 정식 의제로 반영되기는 했지만 본격적인 논의는 2011 년부터 활성화될 것으로 전망된다. 동 이슈에 대한 논의는 빈곤퇴치 및 빈곤 친화적 성장에 있어서 빈곤계층에 대한 사회적·제도적 보호는 필수적이라는 인식에서 출발하고 있으며, 따라서, 논의의 주된 목적은 수원국이 빈곤층에게 최소한의 사회적 보호장치를 마련하여 취약성을 완화시킬 수 있는 제도적이고 지속적인 사회보장체게를 수립하는 것을 지원하는 데 있 다. 특히 최근 글로벌 경제위기의 영향이 개발도상국 빈곤층에게 더 큰 것으로 나타남에 따라 POVNET 활동에서의 동 이슈의 비중은 높아가고 있다.

실제로, 근래 양자/다자 공여기관, 국제 NGO 등 다양한 주체들이 사회적 보호 관련 연구 및 활동 을 활발하게 진행 중에 있으며, 세계은행은 동 주제 관련 전략보고서를 보유하고 있을 뿐 아니라 사회보험, 연금 프로그램 등과 관련한 사업을 실시하고 있다. 이러한 상황에서 POVNET 차원의 add value 전략은, 기존 이니셔티브 및 교훈들을 국제기구 $\mathrm{UN}, \mathrm{DAC}$ 회원국들로부터 수집하여 관련 원조통계 자료 등을 생산하고 나아가 사회보장 분야에 대한 원조재원의 배분 및 전략 규범 등을 제시하는데 일차적 목적을 둘 예정이다. 이를 위해 POVNET은 동 work stream의 체계적 진행을 위한 Task Force를 구성할 것으로 보이므로 우리나라도 참여를 검토할 필요가 있다.

\section{4. 식량 안보(Global Food Security)}

식량안보 이슈는 지난 $2010 \mathrm{MDG}$ 정상회의에서 행동강령으로 채택되어 MDGs 달성의 중요한 요소 로 인식되고 있으며, 아울러 서울 G20 정상회의에서도 이와 관련한 행동계획이 합의된 바 있다. POVNET에서는 글로벌 식량안보, 특히 최빈개도국의 식량문제의 개선을 위해서는 각 공여국들의 
농업 및 무역정책 등과 아울러 개발원조의 역할도 매우 중요하므로 각국이 농업 및 식량원조와 관 련된 국가차원의 서약(commitment)을 실제로 현장에서 이행하는 것을 모니터링하는 방안을 검토 하고 있으며, 아울러 파리선언에 입각하여 각 개도국이 식량안보에 대한 역량을 강화할 수 있도록 지원하는 방안을 모색할 예정이다. 아울러 POVNET은, 농업과 식량 안보와 관련한 공여기관들의 효과적 사업실시를 위해 다양한 정책 보고서를 제공할 계획이며, 동 보고서는 빈곤 친화적 성장과 농업, 고용, 사회적 보호, 역량강화 팀의 활동 등 POVNET의 기존 논의를 바탕으로 작성될 예정 이다. 또한, $\mathrm{DAC}$ 차원에서도 $\mathrm{CRS} 11$ ) 통계를 활용하여 식량안보와 관련된 개발재원의 흐름을 파악 하고 국제적 약정 이행을 모니터링하며 공여국들에게 농업과 식량안보와 관련한 지원의 가이던스 를 제시하는 등 $\mathrm{PD} / \mathrm{AAA}$ 의 원칙들이 식량안보 분야에도 효과적으로 적용될 수 있도록 권고를 시 행할 계획이다.

\section{5. 빈곤 친화적 녹색 성장 (Greening pro-poor growth)}

기후변화 및 환경파괴는 자연자원에 대한 의존성이 높은 최빈개도국과 극빈층에게 상대적으로 더 심각한 영향을 미치고 있는 상황에서 환경적 고려를 배제한 개발과 성장, 빈곤퇴치는 지속성을 유 지하기 어렵다는 관점에서 동 이슈에 대한 논의가 출발한다. 나아가 POVNET에서는 기후변화 및 환경 이슈와 글로벌 빈곤퇴치를 통합하는 새로운 접근법을 모색하고 있으며, 구체적인 방안으로 녹색성장전략과 빈곤퇴치간의 연관성 연구, 농업 및 인프라 지원에 있어서의 친환경적 고려 방법 등을 연구하여 공여국들을 대상으로 하는 정책지침서 작성 등을 고려하고 있다. 이러한 방침하에 POVNET 사무국에서는 지금까지 인프라, 농업 등의 분야에 가이던스를 제공해온 경험을 바탕으로 빈곤층에 대한 영향을 포함한 빈곤 친화적 녹색성장 이슈를 발전시켜 나갈 계획임과 아울러, 이러 한 활동의 성과제고를 위해 DAC/ENVIRONET과의 공조를 강화하여 ENVIRONET의 기존 논의들 (천연 자원, 저탄소 성장, 기후 적응 성장 등)을 보완하여, 에너지, 인프라, 농업 등의 경제 섹터 에서의 공여국 정책 결정에 영향을 줄 수 있는 institutional framework 가이던스를 제공할 계획 임을 밝히고 있다.

11) Creditor Reporting System : OECD/DAC의 원조통계 보고 체계 


\section{V. 우리나라의 대응방향}

\section{POVNET 가이드라인에 대한 이해와 적용}

POVENET의 핵심문서인 DAC Guideline on Poverty Reduction과 Pro-Poor Growth Guideline 은 $\mathrm{DAC}$ 차원에서도 적용의 우선순위가 높을 뿐 아니라 동료심사지침서(Peer Review Contents Guide)에도 반영되어 각 공여국의 원조정책 및 집행현황을 평가하는 중요한 기준이 되고 있다. 따 라서, 금년부터 $\mathrm{DAC}$ 의 정식회원으로 활동하게 된 우리나라도 동 기준들을 정확히 이해하고 개발 원조사업의 발굴, 심사 및 디자인 단계에서 적용시키는 노력을 기울일 필요가 있다.

우선, DAC Guideline on Poverty Reduction에서 제시하고 있는 주요 원칙들은 이후 발표된 $\mathrm{PD} / \mathrm{AAA}$ 의 이행사항과도 일관성을 보여주고 있는데, 가장 초점을 맞추고 있는 규범으로 "수원국 의 주인의식 강화”를 들 수 있다. 지난 세기 원조의 역사를 통해 공여국 주도의 개발원조가 지속 성이나 파급효과 측면에서 한계를 보인 반면, 수원국의 주인의식에 기반한 원조 프로젝트들이 현 지 주민들의 빈곤완화 및 복지향상에 있어 실질적인 기여를 했음을 확인함으로써 그 중요성이 강 조되고 있다. 빈곤문제는 매우 복합적인 요소를 포함하고 있는 만큼 현지의 상황을 가장 잘 이해 하고 있는 각 수원국 정부가 수립한 빈곤퇴치 전략 및 접근을 존중하고 개발원조 등 외부의 개발 재원이 수원국 자체의 국내 개발재원과 조화되고 통합되어 운용되어야 한다는 것이다. 따라서, 수 원국의 빈곤퇴치를 목적으로 하는 우리나라의 개발원조 집행방식도 이러한 접근과 규범을 수용할 수 있도록 원조사업의 사업발굴 방식, 원조 modality, 집행절차 등을 보완해야 할 것이다. 특히, 수 원국의 주인의식 제고를 위해서는 수원국 자체의 국가시스템, 즉 공공재정관리체계(Public Financial Management) 및 조달시스템을 적극적으로 활용할 것을 권고받고 있는데, 이는 수원국의 우선순 위에 따라 개발재원을 효과적으로 배분하고 집행하는데 있어 중요한 선행조건으로 받아들여지고 있기 때문이다.

아울러, “빈곤친화성” 원조에 대한 고려도 강조되어야 한다. 모든 개발원조가 거시적 차원에서는 수원국의 빈곤퇴치 효과를 나타낸다고 볼 수 있지만 제한된 개발재원의 집행에 있어 빈곤과 불평 등 해소는 우선적 고려사항이 되어야 한다. 즉, 개발원조의 혜택이 가급적 보다 지원의 절실성 및 효과성이 상대적으로 높은 빈곤층, 빈곤지역에 미칠 수 있도록 전략적으로 개발정책 및 사업계획 을 수립해야 한다는 것이다. 물론 개발원조는 복합적인 목적과 전략에 의해 추진되므로 빈곤감소 효과를 항상 최우선적 고려사항으로 반영할 수는 없지만 빈곤친화적 고려는 개발원조사업에 있어 어떠한 경우에도 배제될 수는 없는 항목일 것이다. 아울러, 사업의 기획 및 집행단계에서도 빈곤 
친화성은 강조되어야 하는데, 예를 들어 병원건립 프로젝트에 있어 지역 및 부지, 수수료(user $\mathrm{fee}$, 진료과목 등의 결정에 있어 가급적 빈곤층의 상황을 고려하는 노력이 필요할 것이다. 직업 훈련원 건립사업의 경우에도 마찬가지로 실제 빈곤층이 접근하기 상대적으로 용이한 노동시장 및 기술분야에 대한 고려가 있어야 하며, 극빈층12)이 실질적으로 직업교육에 참여할 수 있도록 보조 금(subsidy) 제도 등을 프로젝트 내용에 포함시키는 노력을 기울여야 한다.

빈곤친화적 성장가이드라인(Pro-Poor Growth Guideline)과 관련한 우리나라의 과제들을 살펴보 면, 우리나라가 지원하는 각 수원국의 개발 및 성장전략이 빈곤친화성을 가지고 있는지 분석하는 작업이 선행되어야 할 것이다. 수원국의 국가개발계획(NDP)와 빈곤감소전략(PRSP)의 조화와 균형 여부와 더불어 우리 개발원조가 지원하는 수원국의 분야별 성장정책이 빈곤층의 이익 및 역량을 실제 제고시킬 수 있는지를 분석하는 것도 우리 개발원조의 투입 우선순위 결정에 있어 중요한 고 려사항이 될 수 있기 때문이다. 그것은 우리 개발원조가 빈곤층이 배제되고 불평등이 확산될 수 있는 수원국의 성장전략을 지원하는 결과를 초래하지 않도록 방지하는 역할도 할 수 있다. 지원분 야의 선정에 있어서도 빈곤친화적 성장 관점은 중요한 고려요소인데, 가이드라인에서 제시하고 있 는 바와 같이 경제성장에 있어 빈곤층의 성장기반이 되는 농업, 인프라, 사회보장 등의 분야에 대 한 지원을 확대하는 노력도 병행되어야 한다. 우리나라의 경우 국제사회에서 빈곤층 역량강화에 있어 중요한 이슈로 대두되고 있는 "빈곤층의 취약성을 보완하는 최소한의 사회보장 확대"와 관련 된 분야에 대한 지원을 확대하는 것을 검토해 볼 필요가 있다. 우리나라의 경제성장과 병행하여 발전해온 사회보호 프로그램은 선진국의 사례보다 수원국들에게 보다 현실적인 대안을 제공해 줄 수 있기 때문이다.

금번 동료검토지침(Peer Review Contents Guide) 개정시 Pro-Poor Growth Guideline의 핵심내 용이 반영되어 2011년 동료검토시부터 적용될 예정이며, 2012년 동료검토 수검국으로 확정된 우 리나라도 이에 대한 대비를 해야하는 상황이다. 따라서, 동 가이드라인에 대한 이해와 적용을 위 한 자체적인 역량강화도 우리의 과제가 된 만큼 실제 사업에서의 적용과 더불어 유관 기관 및 인 력들에 대한 교육 등을 강화해야 할 것이다.

\section{Train-4-DEV를 통한 현장역량 강화}

POVNET과 Train-4-DEV 네트워크가 공동으로 실시하고 있는 교육프로그램을 우리나라의 현장

12) 극빈층의 경우 생계문제로 인해 교육기회 참여가 불가능한 현실적 장애가 있으며 각종 수당 및 보조금의 지급을 수반 한 교육프로그램이 필수적임. UNICEF가 실시하는 빈곤층 자녀들의 교육참여 제고를 위한 무상급식사업이 대표적인 사례임. 
개발인력 역량강화를 위한 수단으로 활용하는 방안을 검토할 필요가 있다. 동 프로그램은 빈곤친 화적 성장과 관련한 이슈들에 대한 학습 이벤트를 수원국 현장의 공여국 개발인력들을 대상으로 진행해 오고 있는 만큼 우리나라 인력들도 교육에 참여하여 전문성을 강화함과 아울러 사업발굴 및 기획에 있어 해당 가이드라인 적용 역량을 제고시킬 수 있는 좋은 기회가 될 것으로 생각된다. 특히, 운영 중인 8개 과정 중 농업 및 인프라 관련 과정은 우리나라의 주요 지원분야와 연관성이 높은 것으로 평가된다.

\section{2011-2012 POVNET 의제에 대한 이해와 대응}

POVNET은 2011-2012 PWB의 핵심의제로 글로벌 사회보장 기반 확대, 글로벌 식량안보, 녹생성 장과 빈곤감소 이슈들을 선정하고 활동의 초점을 맞추어 나갈 계획이다. 특히, 사회보장(social protection) 이슈는 근래 국제 개발커뮤니티에서 중요한 이슈로 부각되는 새로운 이슈에 속하는만 큼 우리나라도 동 이슈의 출현배경 및 논의전개방향 등에 대한 관심을 강화하여 향후 논의과정에 서 이니셔티브를 확보해 나가는 방안을 모색할 필요가 있다. 최근 회의에서 회원국들은 논의의 발 전을 위한 사례 수집이 중요함을 역설했으며, 멕시코는 자국의 빈곤층에 대한 사회적 보호체계 사 례를 공유하고 싶다는 의사를 피력한 바 있다. 따라서, 우리나라도 우리의 경험 및 사례를 적극적 으로 제시함으로써 동 이슈의 논의에 기여와 역할을 확대해 나갈 수 있을 것이다.

식량안보 이슈의 경우 $\mathrm{MDG}$ 정상회의 및 서울 $\mathrm{G} 20$ 정상회의에서도 중요성을 인정받은 바 있으므 로 POVNET 차원에서도 지속적인 관심을 기울일 것으로 예상되는 분야이며 향후 관련 보고서 및 가이드라인 생산을 준비 중에 있으므로 우리나라도 이러한 원조규범 형성과정에 적극 참여하여 우 리의 입장과 관점을 반영시켜야 할 것이다. 아울러 동 이슈와 관련된 원조통계 및 공약사항 점검 도 병행될 것으로 예상되므로 우리나라도 대응방안을 마련해야 할 것으로 생각된다.

빈곤친화적 녹색성장 이슈는 이미 환경문제가 개발에 있어서의 고려사항 수준을 넘어서 통합된 개 발전략으로 발전하고 있음을 상징하고 있으며 따라서, 우리나라에게도 환경-개발 이슈에 대한 발 전된 시각을 요구하고 있다. 개발원조사업의 발굴 및 기획단계에서 환경을 고려요소가 아닌 빈곤 퇴치와 성장의 기반으로 이해하는 새로운 시각이 필요하며 이와 관련된 역량강화가 시급한 상황이 다. 따라서, 이러한 필요에 기반한 개발교육, 개발인력 역량강화 프로그램을 도입해야 할 것이다. 


\section{참고 문헌}

DCD/DAC/POVNET, The China-DAC Study Group : Findings to Date and Future plans (Paris: OECD, 2010)

DCD/DAC/POVNET, Summary Record of The Meeting of the Task Team on Empowerment (Paris: OECD, 2010)

DCD/DAC/POVNET, Measuring ODA for Social Protection, (Paris, OECD, 2010)

DCD/DAC/POVNET, POVNET Work Streams 2011-2012, (Paris: OECD, 2010)

DCD/DAC/POVNET, Draft Guidance on Donor Support for Empowerment Processes Underpinning Pro-poor Growth, (Paris: OECD, 2010)

DCD/DAC/POVNET, Progress Report on the Learning Events with the TRAIN-40DEV Network on Promoting Pro-Poor Growth, (Paris: OECD, 2010)

DCD/DAC/POVNET, Summary Record of the Task Team on Empowerment, (Paris: OECD, 2010)

DCD/DAC/POVNET, Joint Learning Events Organized by the TRAIN-4-DEV Network on Pro-Poor Growth and on Social Protection-progress Report, (Paris: OECD, 2010)

DCD/DAC/POVNET, Summary Record of the Task Team on Pro-Poor Growth, (Paris: OECD, 2010)

DCD/DAC/POVNET, Accelerating Progress towards the MDGs through Pro-Poor Growth : Policy Message from the DAC Network on Poverty Reduction, (Paris: OECD, 2010)

OECD/DAC, Promoting Pro-Poor Growth : Policy Guidance for Donors, (Paris, OECD, 2007) OECD/DAC, DAC Guideline on Poverty Reduction, (Paris, OECD, 2001)

ODI, Agriculture and Pro-poor Growth, (London, 2009)

UN General Assembly, Keepring the Promise : a forward-looking review to promote an agreed action agenda to achieve the Millenium Development Goals by 2015 , (New York, UN, 2010) 